\title{
ROLE OF LOCAL GOVERNMENT IN SUPPORTING LOCAL SOCIAL CAPITAL
}

\section{ÚLOHA MIESTNYCH SAMOSPRÁV PRI PODPORE MIESTNEHO SOCIÁLNEHO KAPITÁLU}

\section{DOC. ING. DANa ĠIHLOVÁ, PhD. MGR. ŌUBOSLAVA KUBIǴOVÁ}

\author{
Katedra verejnej ekonomiky a regionálneho rozvoja $\mid$ Depart. of Public Economy and Reg. Development \\ Ekonomická fakulta Faculty of Economics \\ Univerzita Mateja Bela v Banskej Bystrici Matej Bel University Banska Bystrica \\ $\bowtie$ Tajovského 10, 97590 Banská Bystrica, Slovakia \\ E-mail:danka.svihlova@umb.sk,luba.kubisova@umb.sk
}

\begin{abstract}
Annotation
Endogenous theories of regional development consider social capital as one of the important development factors. From the perspective of the local government it should be taken into consideration as having a significant potential for local economic and community development. This potential can be deployed for achieving the common good. The aim of the article is to emphasise the role of local governments in building and maintaining bridging social capital in rural areas in Slovakia. This type of social capital plays an important role in the formation of Local Action Groups. The methods used in this study involved literature review in the field of social capital and a survey conducted among Local Action Groups in Slovakia.
\end{abstract}

\section{Key words}

social capital, local government, local action groups, Slovakia

\section{Anotácia}

Endogénne teórie regionálneho rozvoja povaǵijú sociálny kapitál za jeden z dôleǵitých faktorov rozvoja. Z pohQ̆ıdu miestnych samospráv je potrebné sústrediŚs sa na jeho významný potenciál pre miestny a komunitný rozvoj. Tento potenciál môǵe byŠ vyuğitý na dosiahnutie spolo!̣ ných cie@̆v. Cieढ̆m tohto ḷánku je zdôrazniŠ úlohu miestnych samospráv pri budovaní a udrǵavaní premosŠvacieho sociálneho kapitálu vo vidieckych oblastiach na Slovensku. Tento typ sociálneho kapitálu zohráva dôleǵitú úlohu pri vytváraní Miestnych ak! ných skupín. V ğúdii sme pouǵili metódy preh@̆ıdu a sumarizácie literatúry v oblasti sociálneho kapitálu a prieskum medzi Miestnymi ak! nými skupinami na Slovensku.

KŎịové slová

sociálny kapitál, miestna samospráva, miestne ak!̣ né skupiny, Slovensko

\section{JEL classification: $Z 130$}

\section{Introduction}

Endogenous theories of regional development consider social capital as a significant factor in local economic and community development. The public/collective character of social capital has been promoted by R. Putnam (1993), who emphasised its positive outcome on public governance and regional development. Since the intangible factors of economic development started to be more and more prominent in the knowledge-based economy, social capital became focus of development 
economics and interdisciplinary studies that deal with the factors of uneven economic development across nations and regions. These efforts have been supported by many governments in economically advanced countries and supranational organisations dealing with economic development (OECD, World Bank). It has been acknowledged that local social capital can be influenced by local/regional/national policies and an institutional setup. As local self-governments are the key actors in the development of their territories, it should be worthwhile to investigate what they can do to ñmanageò the stock of local social capital - social capital generated by and available to a local community. Both the theory of social capital and empirical studies in the field suggest that a right mix of different types of social capital ï bonding, bridging and linking - is essential for pursuing local and regional development. In addition, it is important that the network of relations on a local level includes not only individuals but also organisations (Trigilia, 2001) and policies for local development are formulated and implemented through a close co-operation between public and private actors to be more effective.

Results of the European Values Surveys (Kusá, Tígik, 2009) as well as other empirical studies of social capital in Slovakia (Gajdog Pagiak, 2008) show that there is low level of bridging social capital, i.e. the type of social capital that is expressed by the level of associational life, volunteering, participation and generalized trust. Authors warn that it may lead to stagnation in local development, as more and more external financial resources for improving the living conditions in smaller communities can be accessed only on the basis of grant schemes that rely heavily on associational and volunteering activities of local citizens. On the other hand, family and friendship are held to be very important by Slovaks, which means that bonding social capital is very strong. This is the challenge for public policies, especially on a local level, as these could be used to transform the close relations within family and friendship networks into positive resources for local development (Trigilia, 2001).

\section{Research objective and methodology}

The methods used in this study involved literature review in the field of social capital and a survey conducted among Local Action Groups in Slovakia. The article first reviews the literature on social capital in the context of regional, local and community development to establish a potential role of local governments in building and enhancing bridging social capital in their territories. The results of the literature review are compared with the results of the survey among Slovak Local Action Groups. In the survey, the representatives of all 29 Local action groups were approached with a questionnaire containing six questions. Three of the questions were open ended and two of them had the options to rank the importance of given factors and actors in establishing their LAG. The survey was carried out through an electronic on-line questionnaire in April 2014. 24 filled-in questionnaires were received, which means the return of almost $83 \%$.

\section{Social capital as a factor of local and regional development}

The concept of social capital encompasses a wide range of definitions and ideas. From the point of view of local and regional development we will focus on the definitions of the concept that underlines its collective and public good character (as defined by Coleman, 1993, Putnam, 1993, OECD, 2001 and others) as opposed to an individualist understanding of it as a resource that can be drawn upon primarily by an individual or a group for their own benefit (Bourdieu, P., Wacquant, 1992, p. 119 in Kusakabe, 2012). In line with J. Coleman (1993) we consider social capital as a resource that enhances the productivity of other three types of capital, being physical, financial and human capital, and understand that social capital within the social structure does not serve only to actors that actively ñinvestò in it, but also all other individuals that are part of the structure. This makes social capital largely a public good, which means that it can be used by all members of the group and not only the ones who invested in it. As a result, social capital is normally created as a by-product of other activities rather than being a product of direct investment of individuals into it. Coleman also demonstrated how social capital benefits formation of human capital and may be used in supporting collective action, which makes it an attractive concept for the area of public policy. 
Generally conceived as a multifaceted and multidimensional phenomenon, the concept of social capital is composed of several aspects and is applicable on a different scale. Most definitions of social capital thus include the reference to social networks, norms and trust. The scale of the networks, i.e. whether they are closely knit networks of family members and close friends with strong bonds or the broad networks of acquaintances across different social and other divides, has a significant effect both on the norms generated by such networks as well as the trust that is associated with them. Thus, most authors dealing with the social capital concept today distinguish between bonding and bridging social capital and acknowledge the different outcomes that each of these may bring both to individuals and the society at large. Some authors go even further and suggest that the outcomes of social capital should be assessed separately for each of its aspect (networks, norms and trust), as their mutual positive correlation is quite low (Van Oorschot, Finsveen, 2010).

The theory of development has been much inspired and influenced by the collective concept of social capital proposed by R. Putnam (1993) who defined social capital as ñfeatures of social organization, such as trust, norms, and networks that can improve the efficiency of society through facilitating coordinated actionsò (Putnam et al., 1993, p. 167). Putnam defined social capital as an aggregate of associational activity which can be measured by memberships in formal and informal associations and the number of these in a region/nation. He also asserted that the performance of regional governments was very much influenced by the associational life and the level of the civic nature of its citizens. Putnamôs concept of social capital has received much attention due to its propensity for generating public goods and favourable outcomes for the society as a whole. However, it has also been criticized for being too broad to be measured, mixing the aspects of social capital with its outcomes and ignoring the role of broader societal institutions and the role of state in its formation and shaping (Sabatini, 2006). That is why we rather refer to the definitions and authors that take into consideration also the institutional context within which the social networks are embedded, notably the state, as playing a central role in the facilitation of social capital (Woolcock, 2001; Ostrom, 2003; Trigilia, 2001; Adger, 2001 in Lehtonen, 2004; Sabatini, 2006 and other). Woolcock (2001) proposes the definition agreed on by several other authors, referring to the social capital as ñnorms and networks that facilitate collective actionò. He asserts that many times, the absence or weakness of formal institutions is compensated by the creation of informal organisations.

As we have mentioned earlier, another important part of the current social capital theory is the distinction between the two basic types of social capital - bonding and bridging (Patulny, Svendsen, 2007). These types are distinguished with respect to the different types of networks in which they originate, and the different types of outcomes they produce. While bonding social capital is based on close relations among similar types of persons regarding class, ethnicity, background or interest and such networks normally comprise family members and close friends, bridging social capital denotes the relations of ñweak tiesò among people with different backgrounds and the networks connecting people across different boundaries. ñBonding networksò are characterized by so called ñparticularized trustò i.e. trust based on knowing each other, accompanied by strong norms of reciprocity and solidarity. Bridging social capital is based on open, or inclusive, networks and is associated with so called ñgeneralizedòtrust, i. e. trust in unknown people, which is considered to be a strong variable in economic development. Some authors distinguish also linking social capital that describes the relations between individuals and groups in different social strata in a hierarchy where power, social status and wealth are accessed by different groups (Cote, Healy, 2001). Woolcock (2001) extends this to include the capacity to leverage resources, ideas and information from formal institutions beyond the community.

The bridging social capital characteristics overlap with the theory of collective action represented by E. Ostrom, who sees an essential role of social capital in controlling rational-choice-oriented human nature. For Ostrom, social capital takes the forms of trustworthiness, networks and formal and informal rules or institutions (Ostrom, Kahn, 2003). She considers trust to be the outcome of the forms of social capital and a key link between social capital and collective action. Similarly, she 
acknowledges the importance of national and regional governmental institutions in affecting the level and type of social capital available to individuals in pursuing development efforts.

To sum up, social capital as a factor of local and regional development refers broadly to characteristics of social structure (both formal and informal social networks) that function as a resource for individuals and groups, combined with cultural (cognitive) components of trust, reciprocity and mutuality, shared norms of behaviour, shared commitment and belonging and effective information channels (CONSCISE, 2007). Participation in voluntary activities seems to be the key to creating the cultural aspects of social capital within communities (McCulloch, A., Mohan, J. Smith, P., 2012). From the local government perspective, then, it is important to support the ñproductiveò social structures, volunteering and social interaction between diverse groups.

\section{The role of local governments in supporting local social capital}

Local governments in Slovakia have a great deal of autonomy from both regional and state administration and as such could be viewed as principal actors in pursuing local development. However, their public funding may often be limited and their size limiting in this area, which makes them ñsentenced toò use all the available resources as effectively and efficiently as they can. In relation to the use of social capital it means nurturing and drawing upon the right mix of bonding, bridging and linking social capital both within their own territories and beyond.

However, the right mix of the three types of capitals is not so easy to strike, as their effects may vary depending on the size of the territory and its community/communities. Excessive bonding social capital within any community could lead to exclusion of outsiders and isolation with all its negative consequences, so the primary role of local government would be to build and maintain bridging social capital. This type of capital is usually associated with formal and informal associations, clubs and churches. It is important for the local government to develop relations with all of them and encourage their mutual cooperation. The networks of bridging social capital should also reach beyond the community and territory and involve other neighbouring communities. Linking social capital could be built by forming relations and keeping contacts with the representatives of regional and national governments and non-governmental organizations. These contacts should prove as a helpful information channel for accessing external funding and developing external networks. Research on the role of cooperation and networks among actors in the regional development, although not connected to the theory of social capital, has been undertaken within a region in the Czech Republic (Duġek, 2010).

Via supporting the networking and sociability within and beyond communities, local governments can strengthen structural form of social capital that brings about the cultural/cognitive aspects such as trust and shared norms. This can be done by providing financial and non-financial support to local associations of citizens, organizing community events, providing the ñmeeting infrastructureò (children playgrounds, parks with benches, sport facilities, etc.) and developing both formal and informal cooperation with other municipalities in the area. As social capital is created mainly as a byproduct of other activities, it is important that people have enough opportunities to spend their free time with and within the community rather than going elsewhere. The cultural/cognitive aspects of social capital can also be strengthened directly by being transparent and encouraging citizensô participation in planning and decision-making processes. This means providing information about the activities of local government and other actors in the community in the form of a local newspaper, municipality website etc., which can help building local identity as well, and by providing opportunities for people to express their ideas and views regarding their needs and expectations for their life in the municipality in the form of polls, public hearings etc.

Supporting social capital is an explicit aim of community development. Community development theory approaches local development in terms of local community development, i. e. increasing the quality of interactions among people living in a specific territory (Flora, Flora, Fey, 2004 In Bernard, 2011). Grihlová (2004) understands the community development as processes leading to empowerment of individuals and their capacity to understand and solve problems of their village or 
town themselves. In the process, people form a community that gives people sense of local identity, develop mutual relations and together build and use local resources. The author provides following principles applied in the community development: engaging citizens into planning, decision-making and implementation of the local development projects, forming partnerships among citizens, public administration and businesses and building active and sustainable communities based on social equity and mutual respect. With respect to putting these principles into practice, it is necessary that there is a certain level and quality of local social capital, which these principles further enhance.

As for building the bridging networks, it seems to be important to bridge not only the various groups of citizens within non-governmental sector, but all stakeholders that participate in the process of local development. These include private businesses and public actors (regional and national authorities). The principle of intersectoral cooperation is also being applied in regional development policies of the European Union and reflected in the requirements for drawing the EU structural funding in rural development (program LEADER). Here, the social capital could directly enhance chances for getting the funding, as in order to be eligible for it, the municipalities must be a part of Local Action Group (LAG) and have prepared integrated development strategy for their common territory. There are 29 such LAGs in Slovakia and they comprise varying number of municipalities ranging from 6 to 44. 24 (almost 83\%) of their representatives responded in our survey. Most of the LAGs were formed either from the former associations of municipalities $(75 \%)$ or the associations formed a part of the LAG $(17 \%)$.

The results of the survey show that from all the potential stakeholders involved in LAG formation (local governments, local leaders, local non-governmental organizations, local businesses, external non-governmental organizations, external businesses, regional governments, state institutions) local governments are considered to be the most important, followed by local non-governmental organizations, local leaders and local businesses. On the other hand, external stakeholdersôlevel of importance is low, with regional government being the most important of these. When asked about the importance of cooperation among different actors in formation of the Local action groups, the LAG representatives ranked as most important the cooperation among the local governments in the given territory, followed by the cooperation of local governments with their citizens and active participation of citizens in the local affairs.

Fig. 1: Cumulative values of importance rankings assigned to the cooperation of different actors in formation of LAGs in Slovakia

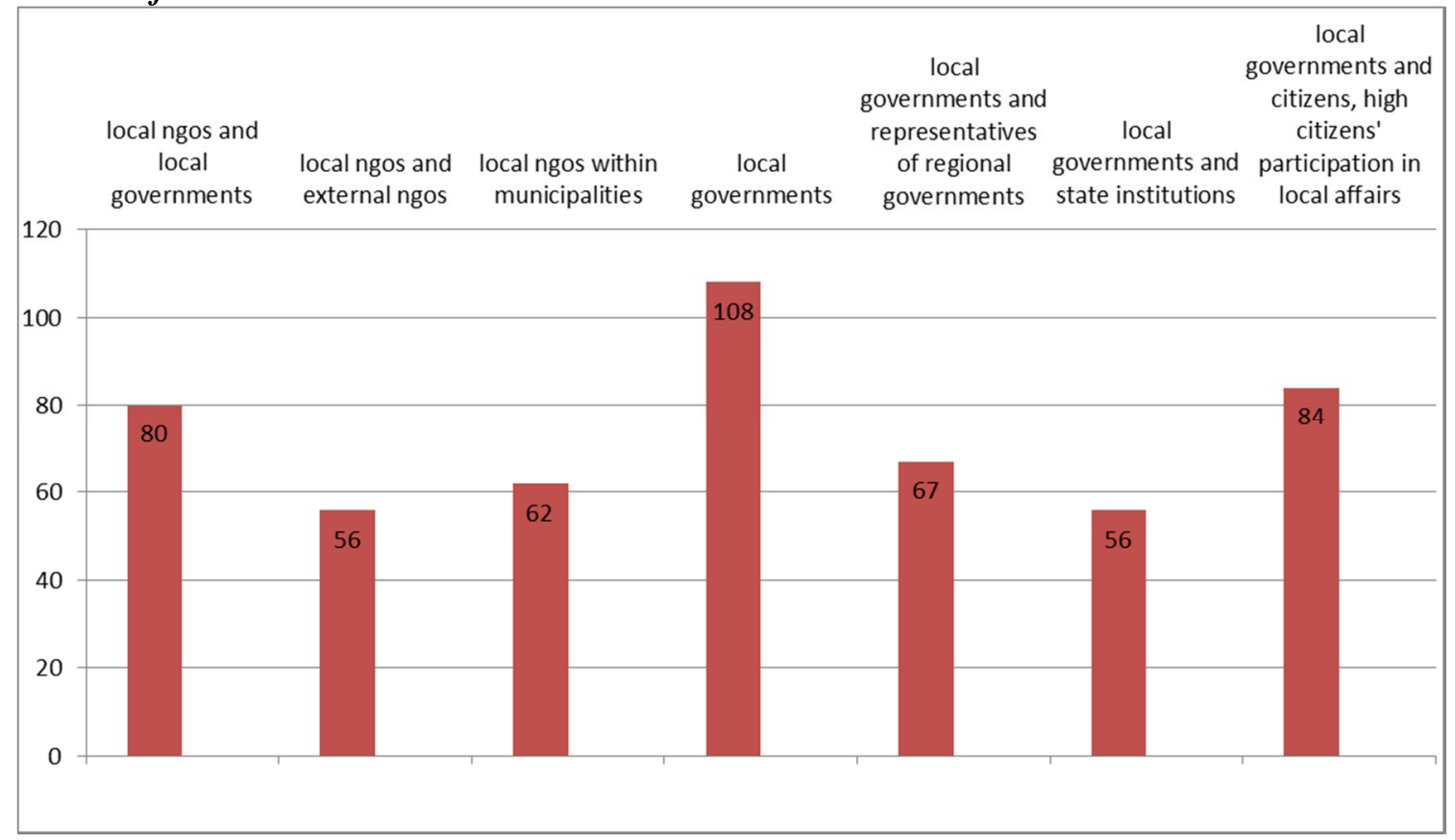

Source: own processing of the survey results 
In the graph above, the values on the y axis refer to the sum of points assigned to the option describing the importance of cooperation of different stakeholders in establishing the LAG. Respondents could assign points from 1 i 5 , with 1 being the least important and 5 the most important. Based on the results of the survey we can also say that it was bridging type of social capital within and beyond the communities that was most important in setting up the LAGs; and that local governments constituted the key part of the bridging networks both within and outside of their municipalities. On the other hand, the role of linking social capital $i ̈$ that of the networks bridging the different levels of power and hierarchy $\ddot{i}$ is deemed less important, as well as bridging networks within municipalities not including local governments.

\section{Conclusion}

Local governments may play a significant role in building and maintaining local social capital as a resource for local development. They need to be able to distinguish between bonding and bridging social capital and try to strike a balance between these two basic types by targeting their support more at bridging social capital. Being aware of the local social capital enables local governments to assess their decisions and plans with view of their potential effects on social capital, which is the first precondition for its effective deployment as a productive resource. It is evident that there is a large pool of external resources for improvement of living conditions in rural localities, if not for their economic development. Although many municipal budgets are not able to cover even the basic needs of the local community, there are possibilities to draw on external resources. As it has been noted above, though, such funds are normally bound to the provision of voluntary work or the existence of a development strategy that is a result of collective efforts either within the community or several communities. In Slovakia, there are only 29 Local Action Groups, including $18.8 \%$ of all municipalities and $11.4 \%$ of the Slovak population, which means that their positive effects, e. g. higher engagement of local actors in public affairs, bottom-up approach, building cooperation and local identity and receiving funding and investments, are confined only to a fraction of the territory and the population. One of the reasons of low coverage of the rural areas of Slovakia by LAGs could be the low level of bridging social capital as identified by the European Value Survey and other studies. Our study confirmed that local governments can play an important role in building and maintaining local social capital. Further research should focus more on specific guidelines for local authorities as to how to use their competencies and instruments to enhance social capital of their communities.

\section{References}

[1] BERNARD, J., (2011). Endogenní rozvojové potenciály malých venkovských obcí ï obtíǵné hledání a mhśení jejich vlivu. Czech Sociological Review, vol. 47, iss. 4, pp. 745 - 775. ISSN 2336-128X.

[2] COLEMAN, J., (1988). Social Capital and the Creation of Human Capital. American Journal of Sociology, 94 Supplement, pp. 52 ï 120. ISSN 1537-5390. DOI 10.1086/228943.

[3] CONSCISE., (2007). The Contribution of Social Capital in the Social Economy to Local Economic Development in Western Europe, EU Research on Social Sciences and Humanities. Final Report, European Communities, Luxembourg. ISBN 97879075674.

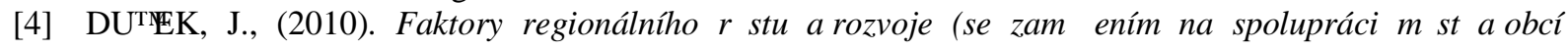
v Jihol eském kraji). L̦eské Bud円ovice: Vysoká ǵkola evropských a regionálních studií, o.p.s. ISBN 97880-86708-94-2.

[5] European observatory on the social situauion - Social capital network., (2007). Social Cohesion, Trust and Participation: Social Capital, Social Policy and Social Cohesion in the European Union and Candidate Countries. Monitoring Report, European Commission.

[6] GAJDOG P., PAĠAK, J., (2008). Sociálne zdroje lokálneho a regionálneho rozvoja : sociologická sonda. Bratislava : Sociologický ústav SAV. ISBN 978-80-85544-53-4.

[7] KUSÁ, Z., TíG̣IK, M., eds., (2009). Výskum európskych hodnôt 1991 - 1999 - 2008: Pramenno-analytická publikácia. Bratislava: Sociologický ústav SAV.

[8] KUSAKABE, E., (2012). Social capital networks for achieving sustainable development. Local Environment, vol. 17, iss. 10, pp. 1043ї 62. ISSN 1469-6711. DOI 10.1080/13549839.2012.714756. 
[9] LEHTONEN, M., (2004). The environmental-social interface of sustainable development: capabilities, social capital, institutions. Ecological Economics, vol. 49, iss. 2 pp. 199-214. ISSN 0921-8009.

[10] MCCULLOCH, A., J. MOHAN, a P. SMITH., (2012). Patterns of social capital, voluntary activity, and area deprivation in England. Environment and Planning, vol. A 44, iss. 5, pp. 1130 ï 47. ISSN 1472-3409.

[11] Národná sieŠrozvoja vidieka. Dostupné z <www.nsrv.sk>

[12] OSTROM, E., KAHN, T.K., (2003). Foundations of social capital. Cheltenham, UK, Northampton, MA: Edward Elgar Pub. ISBN 9781849802499.

[13] PATULNY, R. V., SVENDSEN, G. L. H., (2007). Exploring the social capital grid: bonding, bridging, qualitative, quantitative. The International Journal of Sociology and Social Policy. 2007, vol. 27, iss. 1/2, pp. 32ї 51. ISSN 0144-333X. DOI 10.1108/01443330710722742.

[14] PUTNAM, R. D., LEONARDI, R., NANETTI, R. (1993). Making democracy work: Civic traditions in modern Italy. Princeton, N.J: Princeton University Press.

[15] SABATINI, F., (2006). The Empirics of Social Capital and Economic Development: A Critical Perspective. SSRN Working Paper Series. DOI 10.2139/ssrn.879712.

[16] ĠVIHLOVÁ, D., (2004). Trvalo udrǵateă ý rozvoj na miestnej úrovni. Banská Bystrica : Ekonomická fakulta UMB. ISBN 80-8055-925-2.

[17] TRIGILIA, C., (2001). Social Capital and Local Development. European Journal of Social Theory, vol. 4, iss. 4, pp. 427-442. ISSN 1368-4310.

[18] VAN OORSCHOT, W., FINSVEEN, E., (2010). Does the welfare state reduce inequalities in peopleôs social capital? International Journal of Sociology and Social Policy, vol. 30, iss. 3, pp. 182 -193. ISSN 0144-333X. DOI 10.1108/01443331011033364.

[19] WOOLCOCK, M., (2001). The place of social capital in understanding social and economic outcomes. Canadian Journal of Policy Research, vol. 2, iss. 1, pp. 11-17. ISSN 1208-6037. 